\title{
Melanocortins Mimic the Effects of Leptin to Restore Reproductive Function in Lean Hypogonadotropic Ewes
}

\author{
Kathryn Backholer ${ }^{\mathrm{a}}$ Marissa Bowden ${ }^{\mathrm{b}}$ Kevin Gamber ${ }^{\mathrm{c}}$ Christian Bjørbæk ${ }^{\mathrm{c}}$ \\ Javed lqbal ${ }^{\mathrm{a}}$ lain J. Clarke ${ }^{\mathrm{a}}$

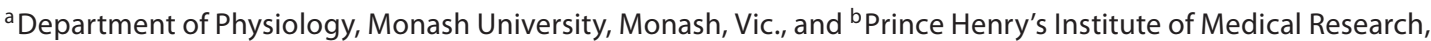 \\ Clayton, Vic., Australia; ' Division of Endocrinology, Beth Israel Deaconess Medical Center and Harvard Medical \\ School, Boston, Mass., USA
}

\section{Key Words}

Proopiomelanocortin $\cdot$ Gonadotropin-releasing hormone $\cdot$ Luteinizing hormone $\cdot$ Hypothalamus • $\alpha$-Melanocyte-stimulating hormone

\begin{abstract}
Background/Aims: Leptin restores gonadotropic function in lean hypogonadotropic animals by an unknown mechanism. We aimed to test the hypothesis that restoration of gonadotropic function is a result of an upregulation of central acetylated melanocortin production. Methods and Results: Lean ovariectomised (OVX) ewes received intracerebroventricular (i.c.v.) infusions of leptin (or vehicle) for 3 days, which upregulated proopiomelanocortin (POMC) mRNA and restored pulsatile luteinizing hormone $(\mathrm{LH})$ secretion. A melanocortin agonist (MTII), but not naloxone treatment, reinstated pulsatile LH secretion in lean OVX ewes. We treated (i.c.v.) lean OVX ewes with leptin (or vehicle) and measured peptide levels and post-translational modification in the arcuate nucleus (ARC). Levels of $\beta$-endorphin ( $\beta$-END) were lower in lean animals, with no effect of leptin treatment. Desacetyl- $\alpha$-MSH was the predominant form of $\alpha$-melanocyte-stimulating hormone ( $\alpha-\mathrm{MSH})$ in the ARC and levels were similar in all groups. In another group of lean and normal-weight OVX ewes, we measured the different forms of
\end{abstract}

$\alpha$-MSH in ARC, hypothalamus (ARC-removed) and the preoptic area (POA). Acetylated $\alpha$-MSH levels were lower in lean animals in the terminal beds of the hypothalamus and POA but not the ARC. Conclusions: Leptin corrects the hypogonadotropic state in the lean condition by upregulation of POMC gene expression, and may increase transport and acetylation of melanocortins to target cells in the brain. Melanocortin treatment restores LH secretion in lean animals.

Copyright $\odot 2009$ S. Karger AG, Basel

\section{Introduction}

Leptin is produced by adipose tissue and signals metabolic status to the brain to regulate food intake and energy expenditure $[1,2]$. Leptin also restores reproductive function in animals genetically deficient in leptin [3] and restores the pulsatile secretion of luteinizing hormone $(\mathrm{LH})$ in lean ovariectomized (OVX) ewes that are hypogonadotropic [4]. The central action of leptin is transmitted via the signaling form of the leptin receptor (Ob-Rb), which is found in a variety of neurons, especially those that produce the peptides/neurotransmitters that control food intake, metabolic function and energy expenditure [5]. Most of the so-called 'appetite-regulating peptides' also regulate reproductive function, acting within the

\section{KARGER \\ Fax +4161306 1234 \\ E-Mail karger@karger.ch}

www.karger.com (c) 2009 S. Karger AG, Basel

0028-3835/10/0911-0027\$26.00/0

Accessible online at:

www.karger.com/nen
Iain J. Clarke

Department of Physiology, Monash University

PO Box $13 \mathrm{~F}$

Clayton, Vic. 3800 (Australia)

Tel. +61 39905 2554, Fax +61 39905 2566, E-Mail iain.clarke@med.monash.edu.au 
brain [6] to regulate gonadotropin-releasing hormone (GnRH) secretion [7]. Neuropeptide Y (NPY), agouti-related peptide (AgRP), and melanocortins are examples of peptides with such dual functions [8-11].

The proopiomelanocortin (POMC) cells of the arcuate nucleus (ARC) also express $\mathrm{Ob}-\mathrm{Rb}$ and a proportion of these express estrogen receptor- $\alpha$ in rats $[12,13]$ and sheep $[5,14]$. The POMC prohormone is post-translationally cleaved to produce $\beta$-endorphin $(\beta$-END) and the melanocortins, $\alpha$-melanocyte-stimulating hormone $(\alpha-\mathrm{MSH}), \beta$ - and $\gamma-\mathrm{MSH}$ [15]. Endogenous opioids, including $\beta$-END, negatively regulate reproduction [16] and stimulate food intake [17]. On the other hand, the melanocortins reduce food intake [18] and stimulate reproduction [19], acting via the melanocortin receptors (MC-R), MC-3R and MC-4R. The generation of $\alpha-\mathrm{MSH}$ and $\beta$-END from the same POMC precursor involves complex post-translational processing by prohormone convertase 1 and 2 . In addition, carboxypeptidase E 'trims' the carboxy terminus and the peptidyl $\alpha$-amidating mono-oxogenase enzyme amidates the $\mathrm{C}$-terminus to enable bio-activity. Acetylation of the $\mathrm{N}$-terminus increases the ability of $\alpha-\mathrm{MSH}$ to reduce food intake, but acetylation of $\beta$-END nullifies activity $[20,21]$. The enzyme(s) (acetylase) responsible for this process have not been identified.

With respect to melanocortin action on the reproductive axis, Watanobe et al. [19] showed that the MC3R/MC4-R antagonist SHU9119 or HS014 (a selective $\mathrm{MC} 4$ receptor antagonist) could reduce the effectiveness of leptin to restore gonadotropin secretion in starved rats. Other work indicated that $\alpha-\mathrm{MSH}[22]$ and $\gamma-\mathrm{MSH}$ [23] stimulate LH release in humans and that $\gamma-\mathrm{MSH}$ causes GnRH release from hypothalamic explants [23]. On the other hand, the MC3-R/MC4-R agonist melano$\tan$ II (MTII) had no effect on gonadotropin levels in male ob/ob mice [24], suggesting a possible species difference.

An ovine model of long-term restricted feeding results in a hypogonadotropic condition which, unlike the starved rat, is not catabolic and is more comparable to the human condition of lean condition caused by dieting or over-exercise. In contrast to the rat where POMC cells are located in the ARC and NTS [25], POMC cells are located exclusively in the ARC in both sheep (Clarke, unpublished data) and humans [26], and both of these species are able to produce $\beta-\mathrm{MSH}[27,28]$, which is not produced from the rodent POMC precursor [29].

Although it is clear that leptin can restore gonadotropic function in hypogonadotropic animals of lean body condition, the means by which this occurs is unknown. The aim of the present studies was to reveal this mechanism using lean hypogonadotropic sheep. We tested the hypothesis that leptin upregulates POMC gene expression and melanocortin production leading to restoration of reproductive function in lean animals. Our results show leptin can upregulate hypothalamic POMC expression and restore LH pulsatility. Furthermore, MTII given centrally is sufficient to restore LH pulsatility in lean hypogonadotropic ewes. We also present peptide data which shows that acetylated melanocortins in the terminal beds are downregulated at times of reduced leptin levels. We conclude that in the brain acetylated melanocortin peptides may mediate regulation of reproductive function by leptin in sheep.

\section{Materials and Methods}

\section{Ethics}

These experiments were conducted with prior institutional ethical approval under the requirements of the Australian Prevention of Cruelty to Animals Act 1986 and the Code of Practice for the Care and Use of Animals for Scientific Purposes. The animals of this study were inspected by members of the Ethics Committee.

\section{Animals}

Adult Corriedale ewes were maintained on pasture or in feedlots, but for intensive experimentation, they were housed individually with natural lighting and temperature and were fed lucerne chaff. Before infusions or sampling, animals were conditioned to pen-housing and handling for 1 week. In experiments where OVX animals were used, the ovariectomies were carried out at least 1 month beforehand to eliminate cyclic alterations in the secretion of gonadal steroids. Third ventricular and lateral ventricular (LV) cannulations were performed at least 2 weeks prior to experimentation as previously described $[4,30]$. Animals were made lean by dietary restriction over a period of 6-10 months as described [31]. Briefly, they were fed $500 \mathrm{~g}$ of pasture hay per day supplemented with straw for bulk. We did not allow our animals to become emaciated and aimed to achieve body condition scores of 2, which indicate a lean condition whereby the ends of the short ribs and backbone can just be felt [32]. Animals of normal body weight were kept on pasture, with hay supplementation for maintenance. The animals were weighed monthly and adjustments in food intake were made at the discretion of the animal carer so that target weights of approximately $35 \mathrm{~kg}$ (lean) and 55 $\mathrm{kg}$ (normal) were attained. No animal in the lean group was excluded from feeding by dominant flock-mates. When in single pens, lean animals were fed $500 \mathrm{~g}$ of lucerne chaff per day and normal animals had ad libitum access to food. All experiments were carried out in the nonbreeding season.

Hypogonadotropic condition was defined if one of the following criteria was met: 
(1) mean plasma LH level 50\% less than that of the average plasma LH level observed in animals of normal body weight;

(2) plasma LH pulse amplitude 50\% less than the average plasma LH amplitude in animals of normal body weight; or

(3) plasma LH interpulse interval 50\% greater than the average plasma LH frequency in animals of normal body weight.

Experiment 1: Effect of Leptin on Plasma LH Levels and Expression of NPY, AgRP and POMC in the ARC of Lean Hypogonadotropic OVX Ewes

This experiment was performed to detail the effects of leptin on the expression of key genes in the NPY/AgRP and POMC cells in lean animals in order to define how leptin may transmit information to the reproductive axis. Lean OVX ewes $(33 \pm 2.9 \mathrm{~kg} ; 5$ per group) received third ventricular infusions of either $4 \mu \mathrm{g} / \mathrm{h}$ human recombinant leptin [4] or artificial cerebrospinal fluid (aCSF; $150 \mathrm{~mm} \mathrm{NaCl}, 1.2 \mathrm{~mm} \mathrm{CaCl}, 1 \mathrm{~mm} \mathrm{MgCl}$ and $2.8 \mathrm{~mm} \mathrm{KCl}$ ) as a vehicle at a rate of $55 \mu \mathrm{l} / \mathrm{h}$ for 3 days. Blood samples $(5 \mathrm{ml})$ were collected every $10 \mathrm{~min}$ for $6 \mathrm{~h}$ before infusion and for the final $6 \mathrm{~h}$ of the 72-hour infusion period. Plasma was harvested and stored at $-20^{\circ} \mathrm{C}$ until assayed for $\mathrm{LH}$. At the end of the infusion period, animals were euthanized by an overdose of $20 \mathrm{ml}$ sodium pentobarbital (Lethabarb; Virbac, Peakhurst, N.S.W., Australia) i.v. and the heads were removed and perfused through both carotid arteries with 2 liters of normal saline containing heparin $(12.5 \mathrm{U} / \mathrm{ml})$ followed by 3 liters of $4 \%$ paraformaldehyde in $0.1 \mathrm{M}$ phosphate buffer ( $\mathrm{pH} 7.4$ ), the final liter containing $20 \%$ sucrose. The brains were removed and the hypothalamus was dissected and post-fixed at $4^{\circ} \mathrm{C}$ in fixative containing $30 \%$ sucrose for 7 days. Cryostat sections were cut in the coronal plane $(20$ $\mu \mathrm{m})$, collected into cryoprotectant with $2 \%$ paraformaldehyde and stored at $-20^{\circ} \mathrm{C}$.

In situ hybridization was performed using a ${ }^{35} \mathrm{~S}$ dUTP-labeled riboprobe using a described protocol $[33,34]$. The cDNA probes used were (1) a 511-base rat NPY sequence donated by Dr. Steven Sabol (National Heart, Blood and Lung Institute, Bethesda, Md., USA) [35], (2) a 400-base ovine POMC sequence [36] and (3) a 184-base rat AgRP sequence [37]. Amplification and linearization of plasmid DNA was performed using a standard technique [38].

For each hybridization series, 2 sections per ewe were chosen to represent mid- and caudal regions of the ARC. All cRNA probes were synthesized using a Promega Gemini System II kit (Promega, Annandale, N.S.W., Australia). Following hybridization, slides were dipped in Ilford K5 photographic emulsion (Ilford Imaging, Melbourne, Vic., Australia) and kept at $4^{\circ} \mathrm{C}$ in the dark for either 11 days (NPY) or 7 days (POMC and AgRP). Image analysis was carried out on autoradiographs using coded slides, with the operator blinded to the treatments. As previously described [37], the number of silver grains per cell was estimated in 40 cells per section. Cells were counted when silver grain density was $>5$ times the background and when there was a clearly discernible nucleus.

\section{Experiment 2: Effects of MTII and Naloxone on Plasma LH}

Levels in Normal and Lean OVX Ewes

As the results of experiment 1 showed upregulation of the POMC gene in lean hypogonadotropic ewes, further evaluation of the melanocortin axis and the opioidergic axis was undertaken. Since melanocortins stimulate the reproductive axis [19], restoration of POMC expression and production of melanocortins by leptin could be a means by which the reproductive axis is normalized in lean animals. To test this hypothesis, we determined whether MTII (MC3-R/MC4-R receptor agonist; Phoenix Pharmaceuticals, Belmont, Calif., USA) would restore pulsatile LH secretion as a reflection of $\mathrm{GnRH}$ secretion. Using a crossover design, lean OVX ewes $(36.5 \pm 0.73 \mathrm{~kg} ; \mathrm{n}=9)$ received either MTII $(10 \mu \mathrm{g} / \mathrm{h})$ or aCSF (LV) for $3 \mathrm{~h}$ in alternate weeks. Blood samples $(5 \mathrm{ml})$ were collected every $10 \mathrm{~min}$ for $3 \mathrm{~h}$ prior to and $3 \mathrm{~h}$ during the infusion. Plasma was harvested and stored at $-20^{\circ} \mathrm{C}$ until assayed for LH.

Earlier work [39] suggested that the lean condition may increase negative opioid tone on the reproductive axis. Because the results of experiment 1 led to a focus on the products of the POMC gene, and the transcript of this gene encodes $\beta$-END, we investigated this regulatory mechanism. To determine if the reproductive axis was restrained by negative opioid action in the lean condition, we administered the nonspecific opioid antagonist naloxone. Naloxone was administered first to normal-weight animals to determine the efficacy of a dose of $50 \mu \mathrm{g} / \mathrm{h}$ using animals of $55.5 \pm 0.5 \mathrm{~kg}$. Groups received either naloxone $(\mathrm{n}=5)$ or aCSF $(\mathrm{n}=4)$ for $3 \mathrm{~h}$ by LV infusion in a crossover design. Since the response to naloxone is steroid-dependent [40], the experiment was replicated in OVX ewes with estradiol-17 $\beta$ and progesterone replacement to maximize the chance of an $\mathrm{LH}$ response. The former was administered by subcutaneous implantation of $3-\mathrm{cm}$ implants inserted into the axillary region for 1 month and intravaginal progesterone delivery devices (CIDR: Riverina; Artificial Breeders Ltd., Albury, N.S.W., Australia) were inserted 2 days prior to the study. Naloxone causes a transient response [40] which is limited to the 1st $\mathrm{LH}$ pulse following initiation of treatment. This was observed in the steroid-treated animals of normal body weight, and we repeated the experiment in lean animals (34.52 \pm $0.60 \mathrm{~kg}$ ) with and without sex steroid replacement. Since no response was obtained at this naloxone dose, we tested the hypothesis that opioid tone is increased in the lean animals by infusing a 10 -fold higher dose $(500 \mu \mathrm{g} / \mathrm{h})$ to lean OVX ewes $(37.6 \pm 2.1 \mathrm{~kg}$; $\mathrm{n}=8$ ) treated with sex steroids, using the same protocol as above.

\section{Experiment 3: Effect of Leptin Treatment on Plasma LH} Levels and NPY, $\alpha$-MSH and $\beta$-END Peptide Concentrations in the ARC of OVX Lean Hypogonadotropic Ewes

Leptin treatment of lean hypogonadotropic ewes led to increased POMC gene expression in the ARC and restoration of pulsatile LH secretion. In order to determine that the change in gene expression was translated into a change in peptide levels, we undertook an experiment to measure levels of NPY, $\alpha-\mathrm{MSH}$ and $\beta$-END peptide. Lean $(36.6 \pm 2.1 \mathrm{~kg})$ and normal $(63.3 \pm 6.1 \mathrm{~kg})$ OVX Corriedale ewes were given LV infusions as follows: lean $\operatorname{aCSF}(\mathrm{n}=7$ for LH analysis, 5 for peptide analysis as a result of damaged tissue), lean leptin $(\mathrm{n}=4)$, and normal $\operatorname{aCSF}(\mathrm{n}=4)$. Leptin $(50 \mu \mathrm{g} / \mathrm{h})$ and aCSF were infused at a rate of $55 \mu \mathrm{l} / \mathrm{h}$ for $72 \mathrm{~h}$ with a loading dose of $150 / 165 \mu \mathrm{l}$. Blood samples $(5 \mathrm{ml})$ were collected every $10 \mathrm{~min}$ for $4 \mathrm{~h}$ prior to the commencement of infusions and $4 \mathrm{~h}$ afterwards. Further 10-min blood samples were collected between $20-24 \mathrm{~h}$ and $68-72 \mathrm{~h}$ of the infusion period. Plasma was harvested and stored at $-20^{\circ} \mathrm{C}$ until assayed for $\mathrm{LH}$.

Animals were euthanized at the end of the infusion period and the hypothalami were dissected, snap frozen on dry ice and stored at $-80^{\circ} \mathrm{C}$. The blocks were sectioned at $200 \mu \mathrm{m}$ on a cryostat and 
the ARC was dissected with the median eminence removed. Ten sections were collected and placed in $700 \mu \mathrm{l}$ of $0.5 \mathrm{M}$ acetic acid, boiled for $10 \mathrm{~min}$ and homogenized. The extracts were centrifuged at 7,500 $\mathrm{rpm}$ at $4^{\circ} \mathrm{C}$ for $30 \mathrm{~min}$ and the supernatants were collected for HPLC and $\alpha-\mathrm{MSH}$ enzyme immunoassay (EIA) analysis.

Experiment 4: Quantification of $\alpha$-MSH in Terminal Beds of Normal-Weight and Lean Ewes

The effect of leptin on the levels of $\alpha-\mathrm{MSH}$ in the ARC of lean hypogonadotropic OVX ewes were not as marked as we expected, so further studies were undertaken to measure levels of the peptide in regions of the brain where dense $\alpha$-MSH-immunoreactive terminal beds are observed. This study was performed on lean and normal-weight OVX animals ( $\mathrm{n}=4$ per group), which represented leptin-deficient and leptin-replete states, respectively. The animals were euthanized and the ARC (median eminence-removed), hypothalamus (ARC-removed) and the preoptic area (POA) were collected by fresh dissection, snap frozen on dry ice and stored at $-80^{\circ} \mathrm{C}$. Each tissue region was then extracted (vide supra) and quantified for desacetylated (des- $\alpha-\mathrm{MSH}$ ) and acetylated $\alpha-\mathrm{MSH}$ (act- $\alpha-\mathrm{MSH})$ using HPLC and $\alpha-\mathrm{MSH}$ EIA.

\section{NPY Enzyme Immunoassay}

NPY in ARC extracts were assayed using a competitive binding EIA. Plates were first coated with anti-NPY serum 1:25,000 (Peninsula Laboratories, San Carlos, Calif., USA) in EIA assay buffer $\left(1.42 \mathrm{~g} / 1 \mathrm{Na}_{2} \mathrm{HPO}_{4}, 0.2 \mathrm{~g} / 1 \mathrm{KH}_{2} \mathrm{PO}_{4}, 5.0 \mathrm{~g} / 1 \mathrm{BSA}, 1 \mathrm{ml} / 1\right.$ Tween 20 in water, $\mathrm{pH} 7.4$ ) overnight at $4^{\circ} \mathrm{C}$. The plate was then washed and blocked $\left(8 \mathrm{~g} / 1 \mathrm{NaCl}, 1.42 \mathrm{~g} / 1 \mathrm{KH}_{2} \mathrm{PO}_{4}, 0.2 \mathrm{~g} / \mathrm{K} \mathrm{KCl}, 5.0\right.$ $\mathrm{g} / \mathrm{l} \mathrm{BSA}, \mathrm{pH} 7.4$ ) for $1 \mathrm{~h}$ at room temperature. After washing, standards and samples were added at $100 \mu \mathrm{l} /$ well for $1 \mathrm{~h}$ at room temperature. After removing the supernatant, $100 \mu$ l of biotinylated NPY 1:500,000 (Bachem, Torrance, Calif., USA) was added to all wells, except blank and nonspecific binding wells, for $1 \mathrm{~h}$. The plate was washed and $100 \mu$ l of streptavidin-HRP (BD Pharmingen, Franklin Lakes, N.J., USA) was added for 1 h. Finally, after 3 washes, $100 \mu \mathrm{l}$ of tetramethylbenzidine (Pierce, Rockford, Ill., USA) was added to each well until a strong blue reaction developed in the total binding wells (10-15 $\mathrm{min})$. The reaction was terminated by the addition of $100 \mu \mathrm{l}$ of $2 \mathrm{~N} \mathrm{H}_{2} \mathrm{SO}_{4}$ and the plates were read at $450 \mathrm{~nm}$. The sensitivity of this assay was $8 \mathrm{pg} / 100 \mu \mathrm{l}$.

\section{$\beta$-END Radioimmunoassay}

$\beta$-END concentrations in ARC extracts $(1: 100)$ were measured in duplicate as previously described [41]. $\beta$-END (Bachem, Bubendorf, Switzerland) was iodinated using the chloramine $\mathrm{T}$ procedure [42] and purified by reverse-phase chromatography using a C18-sep-pak column equilibrated with $80 \% \mathrm{MeOH}$ and $1 \%$ FA. This assay had a sensitivity of $10 \mathrm{pg} / \mathrm{ml}$.

\section{$\alpha$-MSH Separation and EIA}

The $\alpha$-MSH peptides were separated by HPLC using a Symmetry C18 $(5 \mu \mathrm{m})$ column $(4.6 \times 150 \mathrm{~mm}$; Waters, Milford, Mass., USA). The mobile-phase was trifluoroacetic acid (0.1\%) acetonitrile:methanol (80:20) gradient, with a flow rate of $1 \mathrm{ml} /$ min. The $\alpha-\mathrm{MSH}$ peptides eluted between $25-30 \%$ acetonitrile:methanol. Fractions $(1 \mathrm{ml})$ were dried and rehydrated with $50 \mu \mathrm{l}$ of EIA buffer $\left(1.42 \mathrm{~g} / 1 \mathrm{Na}_{2} \mathrm{HPO}_{4}, 0.2 \mathrm{~g} / 1 \mathrm{KH}_{2} \mathrm{PO}_{4}, 5 \mathrm{~g} / \mathrm{l} \mathrm{BSA}\right.$, $1 \mathrm{ml} / \mathrm{l}$ Tween 20, $\mathrm{pH}$ 7.4) and assayed to identify the different forms of $\alpha$-MSH using EIA. The protocol was the same as for the NPY EIA, but $50 \mu \mathrm{l}$ volumes were used. Standards were act- $\alpha$ MSH (Bachem, Torrance, Calif., USA), antiserum was sheep anti$\alpha$-MSH (1:25,000; Bachem, Bubendorf, Switzerland), and the label was biotinylated $\alpha-\mathrm{MSH}$ (1:500,000; Bachem). Final reaction with tetramethylbenzidine was $15-20 \mathrm{~min}$. Assay sensitivity was $4 \mathrm{pg} / 100 \mu \mathrm{l}$.

\section{LH Radioimmunoassay}

LH in plasma was measured as previously described [43] using NIH-oLH-S18 as the standard and NIDDK-anti-oLH-I as the antiserum. Iodinated ovine LH ( $\left.{ }^{125} \mathrm{I}-\mathrm{NIDDK}-\mathrm{AFD}-9598 \mathrm{~B}\right)$ was used as a tracer. Assay sensitivity was $0.2 \mathrm{ng} / \mathrm{ml}$ and the interassay coefficient of variation (CV) was less than $15 \%$.

An LH pulse was defined as having occurred when the assay value of a given sample exceeded the assay value of the previous sample by at least 3 standard deviations, as well as other criteria detailed previously [44]. This method uses error estimates generated by the computer program of Salamonsen et al. [45]. LH pulse amplitude was calculated as the difference between the peak pulse and the pre-pulse nadir. The LH interpulse interval was the average time in minutes between 2 successive LH peaks. The mean pre-pulse nadir was calculated as the mean of the lowest hormone value preceding an identified pulse.

\section{Leptin Radioimmunoassay}

Leptin was measured as previously described [46]. The sensitivity of the assay was $0.12 \mathrm{ng} / \mathrm{ml}$ and the intra-assay CV was less than $10 \%$.

\section{Statistics}

Data are presented as means ( \pm SEM). Hormone data were analyzed by repeated measures ANOVA, with least significant differences as a post hoc test. Peptide and mRNA levels were analyzed by 1-way independent measures ANOVA with Tukey's post hoc comparison.

\section{Results}

\section{Leptin Levels}

Leptin levels were lower $(\mathrm{p}<0.05)$ in lean animals $(0.89 \pm 0.1 \mathrm{ng} / \mathrm{ml})$ than in animals of normal weight $(2.4$ $\pm 0.4 \mathrm{ng} / \mathrm{ml})$.

\section{Experiment 1: Effect of Third Ventricular Infusion \\ of Leptin on Plasma LH, and Leptin Levels and \\ Expression of NPY, POMC and AgRP Genes}

Our model of long-term reduced body weight produced a range of LH responses as shown previously [47]. Infusion of the aCSF vehicle had no effect on mean plasma LH levels (fig. 1a), but leptin infusion increased mean LH concentrations ( $\mathrm{p}<0.01)$, LH pulse amplitude $(\mathrm{p}<$ $0.01)$ and the LH pre-pulse nadir $(\mathrm{p}<0.01)$ in lean hypogonadotropic OVX ewes (fig. 1b, c). 


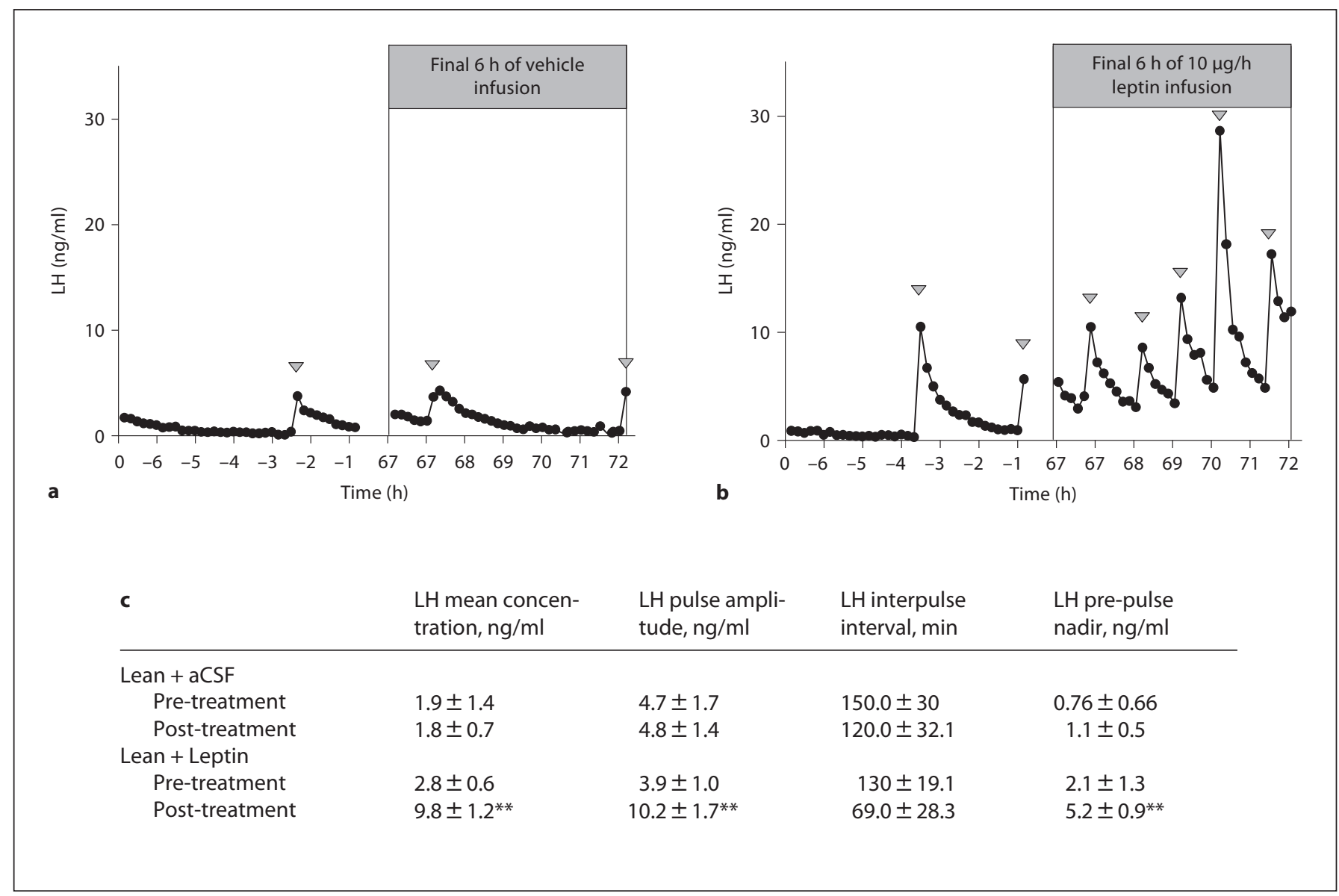

Fig. 1. The effect of third ventricular infusion of aCSF (a) or leptin $(10 \mu \mathrm{g} / \mathrm{h}$; b) for $72 \mathrm{~h}$ on plasma LH levels in lean hypogonadotropic OVX ewes. 10-min blood samples were collected for $6 \mathrm{~h}$ prior to the infusion and for the final $6 \mathrm{~h}$ of the infusion period. c Analysis of mean LH concentration (ng/ml), LH pulse amplitude $(\mathrm{ng} / \mathrm{ml}), \mathrm{LH}$ interpulse interval ( $\mathrm{min}$ ) and $\mathrm{LH}$ pre-pulse nadir $(\mathrm{ng} / \mathrm{ml})$. Arrowheads indicate an LH pulse. ${ }^{*} \mathrm{p}<0.05$ and ** $\mathrm{p}<0.01$ compared to pre-infusion values.
Leptin treatment increased expression of POMC (fig. $2 \mathrm{a}-\mathrm{f}$ ) by increasing the number of detectable cells $(p<0.05)$ and the level of expression per cell $(p<0.05)$. Leptin treatment had no effect on the level of expression of NPY (fig. 2g-l) and AgRP genes (fig. 2m-r).

\section{Experiment 2: Effect of LV Infusion of MTII and}

Naloxone on Plasma LH Levels in Normal and

\section{Lean Hypogonadotropic Ewes}

LV infusion of MTII increased mean LH concentration $(\mathrm{p}<0.01)$, LH pulse amplitude $(\mathrm{p}<0.05)$ and the LH pre-pulse nadir $(\mathrm{p}<0.01)$ compared to pre-treatment $\mathrm{LH}$ levels in lean, hypogonadotropic OVX ewes. Vehicle treatment had no effect. In contrast to the response to leptin, the response to MTII occurred immediately upon the commencement of infusion (fig. 3).

Melanocortin Restoration of Reproductive Function
Naloxone $(50 \mu \mathrm{g} / \mathrm{h})$ increased the amplitude of the 1st $\mathrm{LH}$ pulse following the onset of infusion $(\mathrm{p}<0.01)$ in steroid-treated controls (data not shown). The same treatment had no effect on plasma LH levels in lean hypogonadotropic OVX ewes treated with or without gonadal steroids (fig. 4). The higher dose of $500 \mu \mathrm{g} / \mathrm{h}$ naloxone did not increase plasma LH levels in lean animals (data not shown).

\section{Experiment 3: Effect of Intracerebroventricular} Administration of Leptin on NPY, $\beta-E N D$ and Post-Translationally Modified Forms of $\alpha$-MSH in the ARC of Lean Hypogonadotropic OVX Ewes

Plasma levels of LH were lower in the lean animals than in the normal animals $(5.6 \pm 0.36 \mathrm{ng} / \mathrm{ml})$ prior to treatment. Although the mean plasma LH level and the 


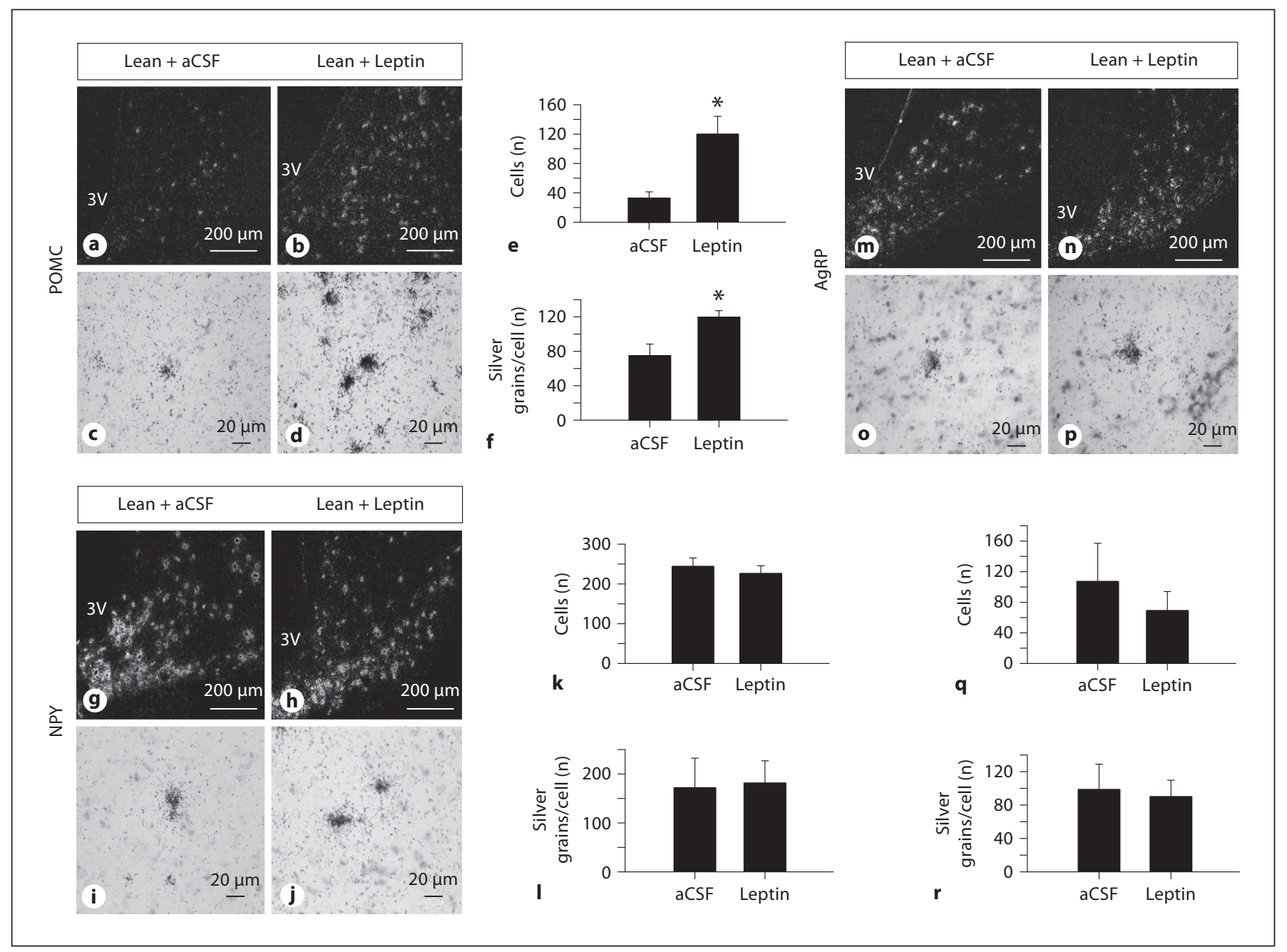

Fig. 2. Effect of third ventricular infusion of aCSF or leptin (50 $\mu \mathrm{g} / \mathrm{h}$ ) for $72 \mathrm{~h}$ on NPY, POMC and AgRP gene expression in the ARC of the hypothalamus of lean hypogonadotropic OVX ewes, as determined by in situ hybridization. a-f POMC gene expression in lean control (aCSF) and lean leptin-treated hypogonadotropic ewes. g-I NPY gene expression in lean control (aCSF) and lean leptin-treated hypogonadotropic ewes. m-r AgRP gene expression in lean control (aCSF) and lean leptin-treated hypogonadotropic ewes. Darkfield and brightfield photomicrographs are taken at $10 \times$ and $40 \times$ magnification, respectively. Data are means \pm SEM. ${ }^{*} \mathrm{p}<0.05$ compared to control.

Des- $\alpha$-MSH was the only form of $\alpha$-MSH detected in the ARC and no $\alpha-\mathrm{MSH}$ of any form was detected in the blank tissue (cerebellum; fig. 5d). Leptin treatment in these animals significantly increased mean LH concentration for the final $4 \mathrm{~h}$ of infusion $(\mathrm{p}<0.05)$ and increased LH pulse amplitude between $20-24 \mathrm{~h}$ of infusion $(\mathrm{p}<0.05)$ and between $68-72 \mathrm{~h}$ of infusion $(\mathrm{p}<0.01)$. The $\mathrm{LH}$ interpulse interval was decreased following leptin treatment between $20-24 \mathrm{~h}$ and $68-72 \mathrm{~h}$ of infusion $(\mathrm{p}<$ 0.01; fig. 5e). ment did not significantly alter the levels of NPY, $\beta$-END or des- $\alpha-\mathrm{MSH}$. 


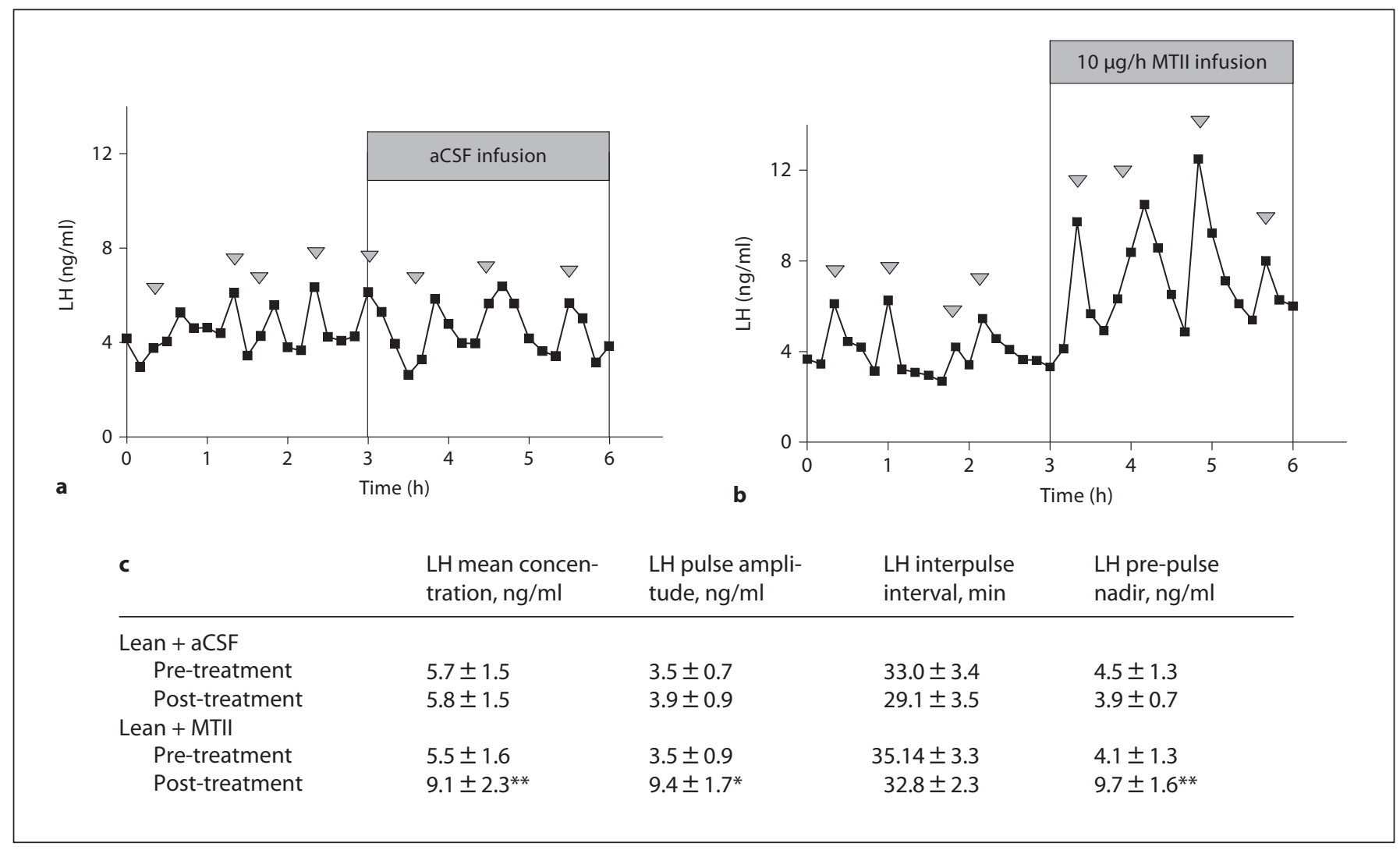

Fig. 3. The effect of LV infusion of aCSF (a) or melanocortin agonist MTII $(10 \mu \mathrm{g} / \mathrm{h}$; b ) for $3 \mathrm{~h}$ on plasma LH levels in lean hypogonadotropic OVX ewes. c Analysis of mean LH concentration,
LH pulse amplitude, $\mathrm{LH}$ interpulse interval (min) and $\mathrm{LH}$ prepulse nadir. Arrowheads indicate an LH pulse. ${ }^{*} \mathrm{p}<0.05$ and ${ }^{* *} \mathrm{p}<0.01$ compared to pre-treatment values.
Experiment 4: Quantification of Des- and Act- $\alpha$-MSH in the Terminal Beds of Normal and Lean Ewes

Des- $\alpha$-MSH tended to be lower in the ARC of lean ewes $(\mathrm{p}<0.059)$. Act- $\alpha-\mathrm{MSH}$ was detected in the ARC of 2 of 4 normal animals, leading to a large standard error for measures in this nucleus (fig. 6a). Act- $\alpha$-MSH levels were lower in the terminal beds of the hypothalamus (ARC removed; $\mathrm{p}<0.05$; fig. $6 \mathrm{~b}$ ) and the POA ( $\mathrm{p}<0.01$; fig. 6c) of lean hypogonadotropic ewes.

\section{Discussion}

POMC gene expression is reduced and NPY gene expression is increased with reduction in body weight, in association with a hypogonadotropic state [48]. Central leptin infusion to the brain restores pulsatile $\mathrm{LH}$ secretion and this is associated with an upregulation of POMC expression, but no change in NPY expression. Because pulsatile LH secretion reflects GnRH secretion [49], we can confidently use the former as an index of the latter. In addition to the response of the POMC gene to leptin treatment of lean hypogonadotropic OVX ewes, we show that treatment of lean animals with a melanocortin agonist, MTII, can restore pulsatile LH secretion. This lends support to the notion that the means by which leptin stimulates $\mathrm{GnRH} / \mathrm{LH}$ secretion may be via the POMC cells and the production of melanocortins. Act- $\alpha-\mathrm{MSH}$ levels in regions of the brain where melanocortin terminal beds are found, viz. the 'non-arcuate' hypothalamus and POA, were lower in lean hypogonadotropic ewes. This strongly suggests that MTII mimics the effects of act- $\alpha-\mathrm{MSH}$ and activates neurons outside of the ARC to stimulate the reproductive axis.

Leptin treatment is able to restore $\mathrm{GnRH}$ and gonadotropin levels in rats [50] and monkeys [51] following 2-3 days starvation, but our model is one in which a hypogonadotropic state occurs due to a reduction in body re- 

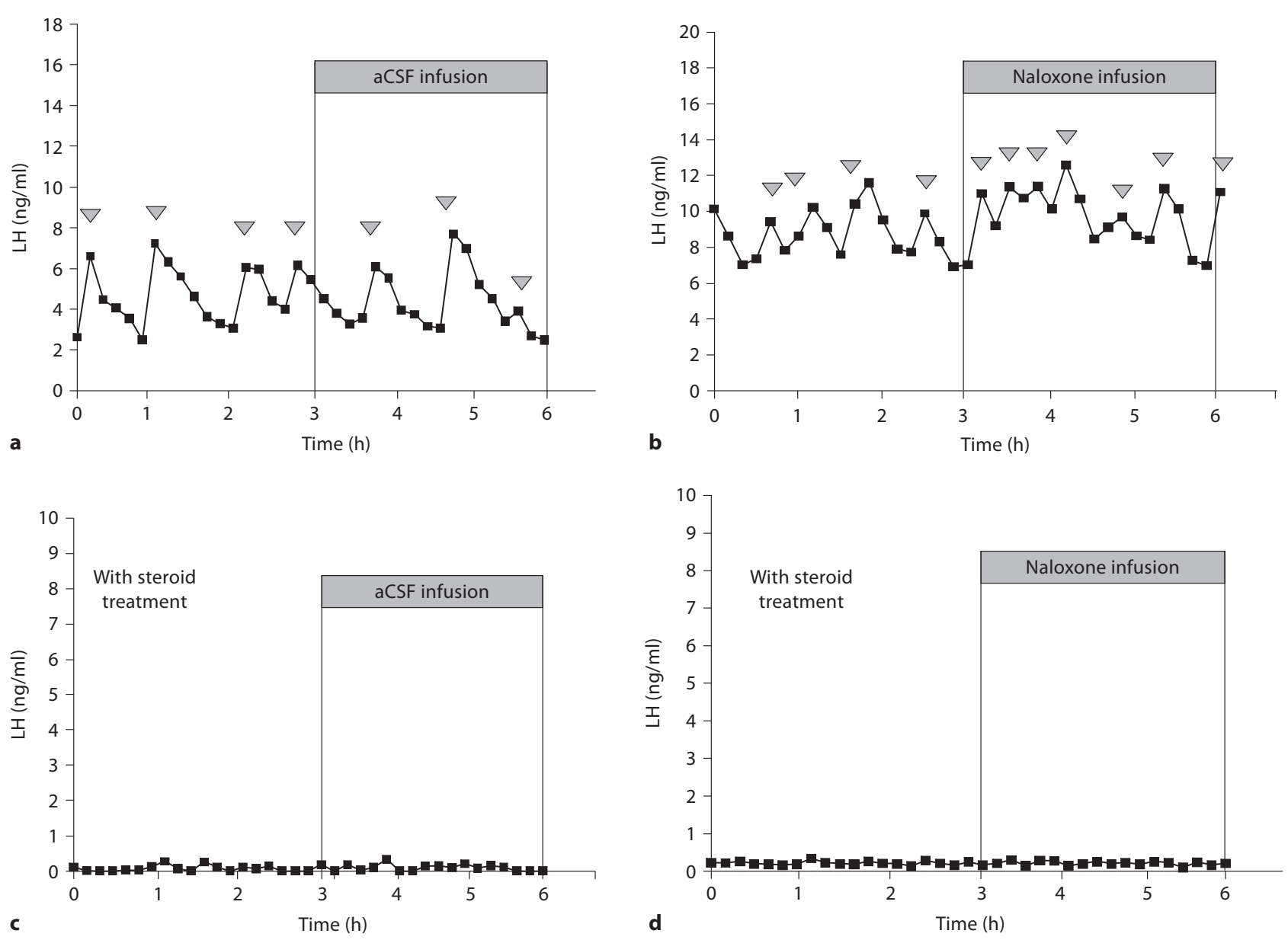

\begin{tabular}{|c|c|c|c|c|}
\hline e & $\begin{array}{l}\text { LH mean concen- } \\
\text { tration, } \mathrm{ng} / \mathrm{ml}\end{array}$ & $\begin{array}{l}\text { LH pulse ampli- } \\
\text { tude, ng/ml }\end{array}$ & $\begin{array}{l}\text { LH interpulse } \\
\text { interval, min }\end{array}$ & $\begin{array}{l}\text { LH pre-pulse } \\
\text { nadir, ng/ml }\end{array}$ \\
\hline \multicolumn{5}{|l|}{ Lean + aCSF } \\
\hline Pre-treatment & $5.9 \pm 1.6$ & $4.4 \pm 0.7$ & $37.5 \pm 3.1$ & $2.9 \pm 1.2$ \\
\hline Post-treatment & $5.6 \pm 1.9$ & $3.7 \pm 1.3$ & $33.8 \pm 5.6$ & $4.2 \pm 1.7$ \\
\hline \multicolumn{5}{|l|}{ Lean + naloxone } \\
\hline Pre-treatment & $4.1 \pm 1.7$ & $2.8 \pm 0.5$ & $32.5 \pm 4.3$ & $1.6 \pm 0.6$ \\
\hline Post-treatment & $4.2 \pm 2.1$ & $2.8 \pm 0.5$ & $34.6 \pm 7.2$ & $2.9 \pm 0.7$ \\
\hline \multicolumn{5}{|l|}{ Lean $+\mathrm{P}+\mathrm{E}+\mathrm{aCSF}$} \\
\hline Pre-treatment & $0.23 \pm 0.04$ & $0.1 \pm 0.0$ & $180 \pm 0.0$ & $0.1 \pm 0.0$ \\
\hline Post-treatment & $0.2 \pm 0.03$ & $0.1 \pm 0.0$ & $180 \pm 0.0$ & $0.1 \pm 0.0$ \\
\hline \multicolumn{5}{|c|}{ Lean $+\mathrm{P}+\mathrm{E}+$ naloxone } \\
\hline Pre-treatment & $0.08 \pm 0.01$ & $0.1 \pm 0.0$ & $180 \pm 0.0$ & $0.1 \pm 0.0$ \\
\hline Post-treatment & $0.45 \pm 0.35$ & $0.075 \pm 0.025$ & $180 \pm 0.0$ & $0.075 \pm 0.025$ \\
\hline
\end{tabular}

Fig. 4. The effect of LV infusion of aCSF or naloxone for $3 \mathrm{~h}$ with $(\mathbf{a}, \mathbf{b})$ or without $(\mathbf{c}, \mathbf{d})$ sex steroids, estrogen (E) and progesterone (P), on plasma LH levels in lean hypogonadotropic OVX ewes. e Analysis of mean LH concentration, LH pulse amplitude, LH interpulse interval (min), and LH pre-pulse nadir. Arrowheads indicate an $\mathrm{LH}$ pulse. 


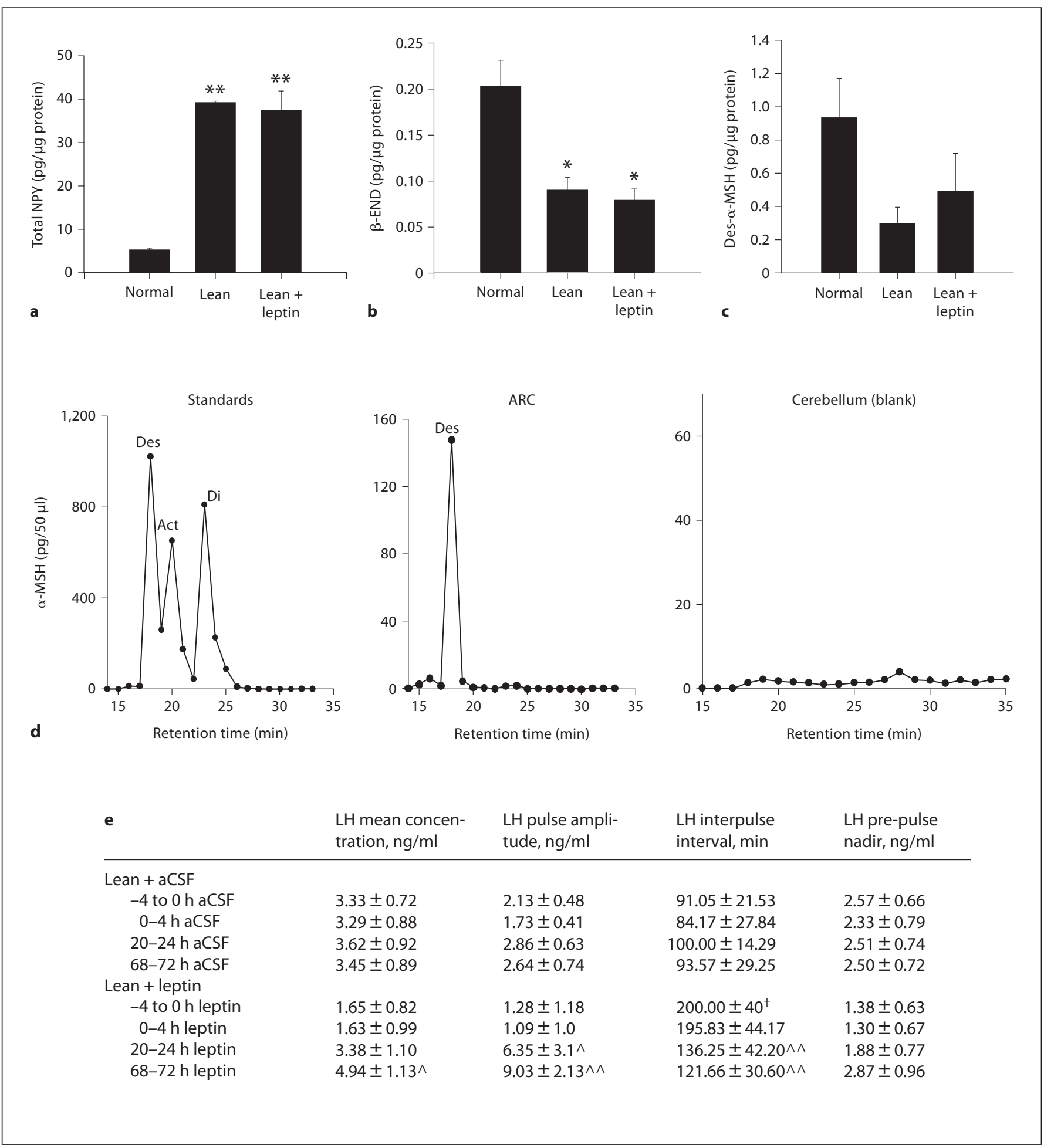

Fig. 5. Mean peptide levels of NPY (a), des- $\alpha$-MSH (b), and $\beta$ END (c) in the ARC of normal, lean, and lean leptin-treated (50 $\mu \mathrm{g} / \mathrm{h}$ ) OVX ewes. All data are presented as means \pm SEM. d HPLC/EIA profile of MSH standards, des- $\alpha$-MSH, act- $\alpha$-MSH and di-act- $\alpha-\mathrm{MSH}$ as well as representative HPLC/EIA profiles in the ARC and cerebellum. e Analysis of mean LH concentration (ng/ml), LH pulse amplitude (ng/ml), LH interpulse interval (min) and LH pre-pulse nadir $(\mathrm{ng} / \mathrm{ml})$ presented as means \pm SEM. ${ }^{*} p<0.05$ and ${ }^{* *} p<0.01$ compared to ewes of normal body weight; $\wedge p<0.05$ and $\wedge \wedge p<0.01$ compared to pre-treatment -4 to $0 \mathrm{~h} \mathrm{LH}$ values; ${ }^{\dagger} \mathrm{p}<0.05$ compared to lean -4 to $0 \mathrm{~h} \mathrm{LH}$ interpulse interval. 

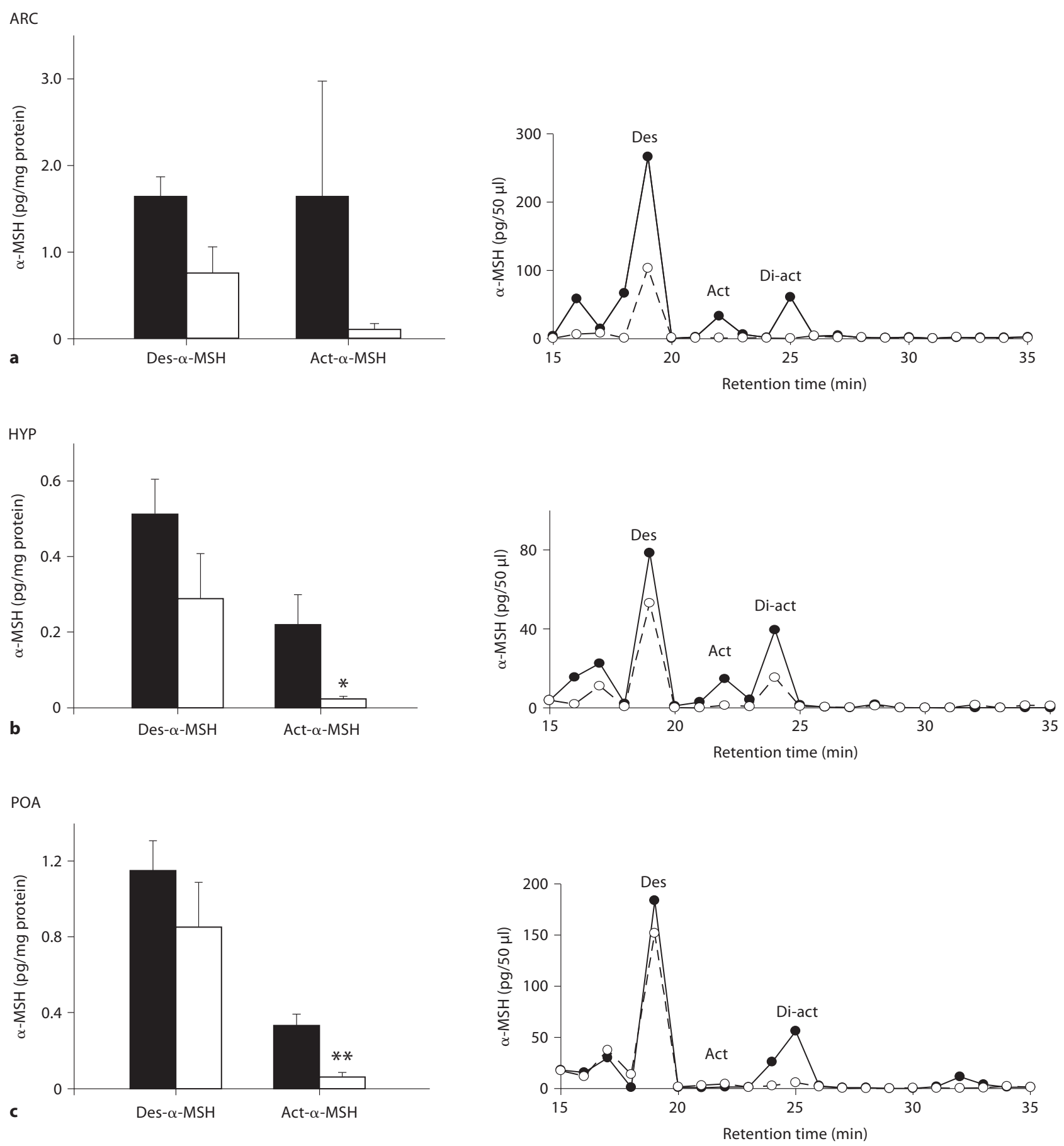

Fig. 6. Mean ( \pm SEM) peptide levels of des- $\alpha-M S H$ and act- $\alpha-$ MSH in the ARC (a), hypothalamus (HYP; ARC-removed; b) and POA (c) of normal weight (solid bar) and lean hypogonadotropic (open bar) ewes and HPLC/EIA representative profiles for each nuclei (the continuous line represents normal weight ewes and the dotted line represents lean hypogonadotropic ewes). ${ }^{*} \mathrm{p}<0.05$ and ${ }^{* *} \mathrm{p}<0.01$ compared to normal-weight controls. 
serves over a long period of time. This is important because, unlike the acute challenge presented to starved laboratory rats, our animals established an altered metabolic set point to normal animals and were not compromised by health. In the long-term food-restricted sheep, leptin treatment restores gonadotropin secretion [4], but re-feeding restores $\mathrm{LH}$ secretion without a change in leptin levels [47], which may be due to altered leptin transport upon re-feeding. Alternatively, the relevant cells in the brain may become more responsive to leptin with re-feeding, but this remains to be determined. Certainly, leptin transport in sheep can change markedly depending on the season [52], so it is possible that it also changes with body weight in sheep. ARC Ob-Rb mRNA is upregulated in lean sheep, but its expression within POMC cells is unchanged with reduced body weight [53]. Notwithstanding these issues, it is clear from earlier studies and the present work that central leptin infusion restores pulsatile LH secretion in our lean hypogonadotropic model, suggesting that the subcellular signaling machinery for leptin action is operative. POMC mRNA levels are reduced and NPY and AgRP mRNA levels are increased in lean fasted rats [54] and in sheep subjected to chronic food restriction $[37,48]$. In some studies, however, this effect of body weight on POMC expression has not been observed, perhaps due to variation between animals [31]. In laboratory rats, leptin treatment is able to reverse the fasting-induced changes in NPY, AgRP and POMC gene expression [54]. The results of the present study yielded a different result, since leptin treatment increased POMC expression without altering either NPY or AgRP expression. For this reason, we focused further on the POMC system.

It seems likely that NPY is elevated in lean ewes as a compensatory mechanism to increase appetite drive. It is possible that leptin cannot restore levels to normal without an increase in body weight because other metabolic factors signal to the NPY cells. The present results concur with our earlier studies [4] showing that central leptin treatment restores LH levels in lean OVX ewes without reducing food intake. This substantiates the notion that NPY expression remains high in these animals to maintain appetite drive until body weight is corrected to normal. The earlier study also showed that treating OVX ewes of normal weight with leptin had the opposite effect, i.e. having no effect on plasma LH levels but reducing food intake [4]. Collectively, these point towards a dissociation between the means by which leptin affects food intake and reproductive function respectively.

Melanocortin Restoration of

Reproductive Function
There is evidence to suggest that an increase in endogenous opioid tone, created by endorphins, enkephalins, dynorphins and endomorphins, is responsible for the suppression of pulsatile LH secretion at times of reproductive quiescence [55]. Consistent with our investigation of the role of the POMC system in the control of reproductive function, especially in the lean condition, we considered it important to entertain the notion that opioids (specifically $\beta$-END) might be involved. This could occur by a preferential increase in $\beta$-END production (through differential post-translational processing in favor of $\beta$-END) and/or increased opioid receptor expression. We present evidence that there is no selective increase in the production of $\beta$-END peptide, and that enhanced opioid tone is unlikely since a 'normal' dose of the nonspecific opioid antagonist, naloxone, or 10 times this dose, did not increase LH secretion in the hypogonadotropic lean animals. This agrees with and extends the results of others [39] who studied food-restricted ewe lambs. There are 2 possible interpretations of these data. One is that the opioid system has no role to play in the reduction of $\mathrm{GnRH} / \mathrm{LH}$ secretion in the hypogonadotropic lean condition. The other is that there is a profoundly enhanced opioid tone. To fully investigate this aspect of the lean condition, it seems most appropriate to examine the role of the dynorphin and enkephalin systems, both of which appear to play an important role in the control of GnRH neurons [56, 57], but this was beyond the scope of the present study, which focused on the POMC neurons. An indication that altered production of $\beta$-END is not the means by which leptin transmits information to the GnRH cells is that leptin treatment did not affect the production of $\beta$-END peptide, even though the same treatment increased POMC expression and pulsatile LH secretion.

On the other hand, MTII restored LH secretion, strongly indicating a role of the melanocortins in the control of the reproductive system at times of compromised energy availability. This notion is supported by rat [19] and human $[22,23]$ studies showing inhibition or stimulation of $\mathrm{LH}$ pulsatile secretion following administration of a melanocortin antagonist or agonist, respectively. We found that MTII acted much faster than leptin in restoring pulsatile LH secretion. Thus, we speculate that the melanocortins act downstream of leptin, and this slower response with leptin indicates slower transcriptional or post-translational events required for leptin to act. Our results are consistent with MTII acting on downstream effector cells, bypassing leptin-mediated effects on POMC cells. In support of this notion are the discov-

Neuroendocrinology 2010;91:27-40 
eries that almost all POMC cells in the ovine ARC express the leptin receptor $o b / r b$ [5], and ovine POMC cells are activated following intravenous leptin injection (Clarke, unpublished data). Additionally, $\alpha$-MSH [22] and $\gamma$-MSH [23] are capable of stimulating LH secretion in humans, and a central melanocortin receptor antagonist can reduce the effectiveness of leptin to restore gonadotropin secretion in starved rats [19]. It does, however, remain plausible that MTII elicits its effect independently of leptin signaling to rescue $\mathrm{GnRH} / \mathrm{LH}$ secretion. Many neuronal systems have been implicated in the regulation of GnRH secretion [58], and the possible involvement of melanocortins does not preclude effects of other systems. It is probable that the melanocortins communicate with numerous different cell types to stimulate the reproductive axis. One possibility is the recently discovered peptide kisspeptin, since Kiss 1 mRNA is downregulated at times of reduced energy stores and treatment with kisspeptin is able to restore vaginal opening and elicit gonadotropin and estrogen responses [59]. Melanocortins may interact with kisspeptin in lean hypogonadotropic states to stimulate the reproductive axis downstream to leptin or independently.

In agreement with our observation that NPY gene expression is strongly upregulated in the lean condition, NPY peptide levels were also increased and leptin treatment was unable to correct this towards normal levels. Although NPY is a negative regulator of the reproductive axis in the ewe [9], the gene expression data and peptide data presented herein suggest that the GnRH/LH response to leptin treatment in lean hypogonadotropic animals is not explained by a reduction in the level of this peptide.

Many studies have focused on POMC gene transcription and how this may or may not change with body weight $[37,48,60]$, but little is known about the peptides produced by post-translational processing of the precursor. Thus, it was considered important to ascertain whether there was a differential shift in the processing of the precursor ( $\beta$-END vs. melanocortins). In agreement with data from the rat [25], we show that des- $\alpha$-MSH is the predominant form of $\alpha-\mathrm{MSH}$ detected in the ARC, but acetylated forms were found in 2 of the normal-weight animals from experiment 4 . This is likely due to the difference in the dissection methods used in experiments 3 and 4 . In experiment 3 , the ARC was removed by microdissection of sectioned tissue, but in experiment 4 we wished to examine tissues in which melanocortin terminal beds are found. Rather than microdissecting very specific regions, we undertook to determine whether there was a generalized difference in the type of melanocortin found in the region of the perikarya of POMC cells (ARC) and areas to which these cells project. In experiment 3, using the more precise dissection method, we showed that ARC samples from lean animals contained des- $\alpha$-MSH only. The presence of acetylated forms of the peptide in the ARC samples of experiment 4 was most likely due to the inclusion of some non-ARC tissue in these samples. We conclude that des- $\alpha-\mathrm{MSH}$ is the major form of $\alpha-\mathrm{MSH}$ in the ARC and that the peptide is acetylated shortly before export from the cell body or in the axons or terminals of the neurons. There was a trend $(\mathrm{p}=0.06)$ towards reduced des- $\alpha$-MSH peptide levels in lean hypogonadotropic conditions in the ARC, and levels in leptin-treated animals were midway between those in normal animals and those in lean animals (not statistically significant). Further work on the acetylation of this and other peptides in the brain is in progress.

Projections of melanocortin-producing neurons, terminal beds [61] and receptors [62] are found throughout the brain. Measurement of the level of function of these neurons will require quantification of the level of peptide that is produced and exported to the neuronal targets. In particular, measuring POMC gene expression and/or des- $\alpha-\mathrm{MSH}$ in the ARC may not indicate the full profile of the melanocortin status of the brain. It has been suggested that leptin acts to increase $\mathrm{N}$-acetyltransferase activity, increasing the amount of the more potent act- $\alpha$ MSH [20,25], and that $\alpha-\mathrm{MSH}$ may be acetylated en route to terminal beds [63]. This is substantiated in the current study, but it would be instructive to identify the enzyme and determine what regulates its activity. Although des$\alpha-\mathrm{MSH}$ is the predominant form in all nuclei analyzed, we believe that the salient changes are seen in the acetylated forms. Another consideration is that change in function of POMC-derived melanocortins is brought about by a change in MC3 and MC4R expression in the brain; however, our earlier studies suggest that expression of these receptors is unchanged by alteration of body weight in sheep [64].

In summary, this study suggests that a link exists between energy stores, the melanocortin system and the reproductive axis. We show that leptin can act to increase POMC gene expression in lean hypogonadotropic animals, suggesting that this leads to increased melanocortin production and function. This correlates to increased secretion of LH in lean animals. Activation of the melanocortin receptor with MTII immediately restores LH levels in lean animals, consistent with the hypothesis that the downregulation of the POMC system is the cause of 
the hypogonadotropic condition in these animals. Act- $\alpha$ MSH levels are lower in the POA and in areas of the hypothalamus outside of the ARC in lean ewes with low leptin levels. We speculate that leptin may increase the acetylation of $\alpha-\mathrm{MSH}$ during neuronal transport, and this acetylated form may act on target cells in the POA and in areas of the hypothalamus outside of the ARC, leading to an increase in pulsatile LH secretion. Melanocortins may have specific utility in the restoration of reproduction in situations of low body weight, caused by excessive exercise or other conditions.

\section{Acknowledgements}

We thank Mr. B. Doughton, Ms. L. Morrish, Ms. Alexandra Rao and Ms. E. Gleeson for their technical assistance; Dr. J. Smith for reviewing earlier versions of the manuscript; and Dr. A.F. Parlow (National Hormone and Peptide Program, NIDDK, Torrance, Calif., USA) for assay reagents. This work was supported by a grant (I.J.C.) from The National Health and Medical Research Council of Australia (N.H. and M.R.C.) and by grants (C.B.) from the American Diabetes Association and The Richard and Susan Smith Family Foundation Pinnacle Program Project (7-05-PPG02), the National Institutes of Health (DK60673 and DK65743), and the Endocrine Society.

\section{References}

1 Friedman JM, Halaas JL: Leptin and the regulation of body weight in mammals. Nature 1998;395:763-770.

2 Clarke IJ, Henry B, Iqbal J, Goding JW: Leptin and the regulation of food intake and the neuroendocrine axis in sheep. Clin Exp Pharmacol Physiol 2001;28:106-107.

-3 Mounzih K, Lu R, Chehab FF: Leptin treatment rescues the sterility of genetically obese ob/ob males. Endocrinology 1997;138:11901193.

4 Henry BA, Goding JW, Tilbrook AJ, Dunshea FR, Clarke IJ: Intracerebroventricular infusion of leptin elevates the secretion of luteinising hormone without affecting food intake in long-term food-restricted sheep, but increases growth hormone irrespective of bodyweight. J Endocrinol 2001;168:67-77.

5 Iqbal J, Pompolo S, Murakami T, Grouzmann E, Sakurai T, Meister B, Clarke IJ: Immunohistochemical characterization of localization of long-form leptin receptor (OB-Rb) in neurochemically defined cells in the ovine hypothalamus. Brain Res 2001; 920:55-64.

6 Clarke IJ, Henry BA: Leptin and reproduction. Rev Reprod 1999;4:48-55.

$\checkmark 7$ Crown A, Clifton DK, Steiner RA: Neuropeptide signaling in the integration of metabolism and reproduction. Neuroendocrinology 2007;86:175-182.

8 Cone RD: Anatomy and regulation of the central melanocortin system. Nat Neurosci 2005;8:571-578.

-9 Clarke IJ, Backholer K, Tilbrook AJ: Y2 receptor-selective agonist delays the estrogeninduced luteinizing hormone surge in ovariectomized ewes, but yl-receptor-selective agonist stimulates voluntary food intake. Endocrinology 2005; 146:769-775.

10 Nijenhuis WA, Oosterom J, Adan RA: $\operatorname{AgRP}(83-132)$ acts as an inverse agonist on the human-melanocortin-4 receptor. Mol Endocrinol 2001;15:164-171.

-11 Schioth HB, Kakizaki Y, Kohsaka A, Suda T, Watanobe H: Agouti-related peptide prevents steroid-induced luteinizing hormone and prolactin surges in female rats. Neuroreport 2001;12:687-690.

12 Cheung CC, Clifton DK, Steiner RA: Proopiomelanocortin neurons are direct targets for leptin in the hypothalamus. Endocrinology 1997;138:4489-4492.

13 Morrell JI, McGinty JF, Pfaff DW: A subset of beta-endorphin- or dynorphin-containing neurons in the medial basal hypothalamus accumulates estradiol. Neuroendocrinology 1985;41:417-426.

14 Lehman MN, Karsch FJ: Do gonadotropinreleasing hormone, tyrosine hydroxylase-, and beta-endorphin-immunoreactive neurons contain estrogen receptors? A doublelabel immunocy tochemical study in the Suffolk ewe. Endocrinology 1993;133:887-895.

15 Pritchard LE, Turnbull AV, White A: Pro-opiomelanocortin processing in the hypothalamus: impact on melanocortin signalling and obesity. J Endocrinol 2002;172:411-421.

16 Bonavera JJ, Kalra SP, Kalra PS: Evidence that luteinizing hormone suppression in response to inhibitory neuropeptides, beta-endorphin, interleukin-1 beta, and neuropeptide-K, may involve excitatory amino acids. Endocrinology 1993;133:178-182.

17 Grandison L, Guidotti A: Stimulation of food intake by muscimol and beta endorphin. Neuropharmacology 1977;16:533-536.

- 18 Fan W, Boston BA, Kesterson RA, Hruby VJ, Cone RD: Role of melanocortinergic neurons in feeding and the agouti obesity syndrome. Nature 1997;385:165-168.

19 Watanobe H, Schioth HB, Wikberg JE, Suda $\mathrm{T}$ : The melanocortin 4 receptor mediates leptin stimulation of luteinizing hormone and prolactin surges in steroid-primed ovariectomized rats. Biochem Biophys Res Commun 1999;257:860-864.

20 Tsujii S, Bray GA: Acetylation alters the feeding response to MSH and beta-endorphin. Brain Res Bull 1989;23:165-169.
21 Abbott CR, Rossi M, Kim M, AlAhmed SH, Taylor GM, Ghatei MA, Smith DM, Bloom SR: Investigation of the melanocyte stimulating hormones on food intake. Lack of evidence to support a role for the melanocortin3-receptor. Brain Res 2000;869:203-210.

22 Limone P, Calvelli P, Altare F, Ajmone-Catt P, Lima T, Molinatti GM: Evidence for an interaction between alpha-MSH and opioids in the regulation of gonadotropin secretion in man. J Endocrinol Invest 1997;20:207-210.

-23 Stanley SA, Davies S, Small CJ, Gardiner JV, Ghatei MA, Smith DM, Bloom SR: GammaMSH increases intracellular cAMP accumulation and $\mathrm{GnRH}$ release in vitro and $\mathrm{LH}$ release in vivo. FEBS Lett 2003;543:66-70.

24 Hohmann JG, Teal TH, Clifton DK, Davis J, Hruby VJ, Han G, Steiner RA: Differential role of melanocortins in mediating leptin's central effects on feeding and reproduction. Am J Physiol Regul Integr Comp Physiol 2000;278:R50-R59.

25 Guo L, Munzberg H, Stuart RC, Nillni EA, Bjorbaek C: N-acetylation of hypothalamic alpha-melanocyte-stimulating hormone and regulation by leptin. Proc Natl Acad Sci USA 2004;101:11797-11802.

26 Zaphiropoulos A, Charnay Y, Vallet P, Constantinidis J, Bouras C: Immunohistochemical distribution of corticotropin-like intermediate lobe peptide (CLIP) immunoreactivity in the human brain. Brain Res Bull 1991;26:99-111.

27 Bertagna X, Seidah N, Massias JF, Lenne F, Luton JP, Girard F, Chretien M: Microsequencing evidence for the maturation of human proopiomelanocortin into an 18 amino acid beta-melanocyte stimulating hormone [h beta MSH(5-22)] in nonpituitary tissue. Peptides 1989;10:83-87.

28 Seidah NG, Crine P, Lis M, Chretien M: Betalipotropin precursor of beta-MSH and betaendorphin. Ann Nutr Aliment 1979;33:5789. 
-29 Pritchard LE, White A: Neuropeptide processing and its impact on melanocortin pathways. Endocrinology 2007; 148:42014207.

30 Henry BA, Dunshea FR, Gould M, Clarke IJ: Profiling postprandial thermogenesis in muscle and fat of sheep and the central effect of leptin administration. Endocrinology 2008;149:2019-2026.

- 31 Henry BA, Tilbrook AJ, Dunshea FR, Rao A, Blache D, Martin GB, Clarke IJ: Long-term alterations in adiposity affect the expression of melanin-concentrating hormone and enkephalin but not proopiomelanocortin in the hypothalamus of ovariectomized ewes. Endocrinology 2000;141:1506-1514.

-32 Russel AJF, Doney JM, Gunn RG: Subjective assessment of body fat in live sheep. J Agric Sci 1969;72:451-454.

- 33 Scott CJ, Pereira AM, Rawson JA, Simmons DM, Rossmanith WG, Ing NH, Clarke IJ: The distribution of progesterone receptor immunoreactivity and mRNA in the preoptic area and hypothalamus of the ewe: upregulation of progesterone receptor mRNA in the mediobasal hypothalamus by oestrogen. J Neuroendocrinol 2000;12:565-575.

34 Simmons DM, Arriza JA, Swanson LW: A complete protocol for in situ hybridization of messenger RNAs in brain and other tissues with radio-labelled single-stranded RNA probes. J Histotechnol 1989;12:169-181.

- 35 Estrada KM, Pompolo S, Morris MJ, Tilbrook AJ, Clarke IJ: Neuropeptide Y (NPY) delays the oestrogen-induced luteinizing hormone (LH) surge in the ovariectomized ewe: further evidence that NPY has a predominant negative effect on $\mathrm{LH}$ secretion in the ewe. J Neuroendocrinol 2003; 15:10111020.

-36 van de Pavert SA, Clarke IJ, Rao A, Vrana KE, Schwartz J: Effects of vasopressin and elimination of corticotropin-releasing hormone-target cells on pro-opiomelanocortin mRNA levels and adrenocorticotropin secretion in ovine anterior pituitary cells. J Endocrinol 1997;154:139-147.

- 37 Henry BA, Rao A, Ikenasio BA, Mountjoy KG, Tilbrook AJ, Clarke IJ: Differential expression of cocaine- and amphetamine-regulated transcript and agouti related-protein in chronically food-restricted sheep. Brain Res 2001;918:40-50.

38 SambrookJ, Fritsch E, Maniatis T: Molecular Cloning, A Laboratory Manual, ed 2. Cold Sping Harbor Laboratory Press, New York, 1989.

39 Recabarren SE, Zapata P, Parilo J: Disappearance of opioidergic tone on $\mathrm{LH}$ secretion in underfed prepubertal sheep. Horm Metab Res 1990;22:225-228.

40 Horton RJ, Francis H, Clarke IJ: Seasonal and steroid-dependent effects on the modulation of LH secretion in the ewe by intracerebroventricularly administered beta-endorphin or naloxone. J Endocrinol 1989;122: 509-517.
41 McCarthy RN, Jeffcott LB, Funder JW, Fullerton M, Clarke IJ: Plasma beta-endorphin and adrenocorticotrophin in young horses in training. Aust Vet J 1991;68:359-361.

42 Greenwood FC, Hunter WM, Glover JS: The preparation of I-131-labelled human growth hormone of high specific radioactivity. Biochem J 1963;89:114-123.

43 Lee VW, Cumming IA, de Kretser DM, Findlay JK, Hudson B, Keogh EJ: Regulation of gonadotrophin secretion in rams from birth to sexual maturity. I. Plasma LH, FSH and testosterone levels. J Reprod Fertil 1976;46: $1-6$.

44 Clarke IJ, Cummins JT: Increased gonadotropin-releasing hormone pulse frequency associated with estrogen-induced luteinizing hormone surges in ovariectomized ewes. Endocrinology 1985;116:2376-2383.

45 Salamonsen LA, Burger HG, Chamley WA, Goding JR: Radioimmunoassay for ovine FSH. J Reprod Fertil 1972;28:131-132.

46 Blache D, Tellam RL, Chagas LM, Blackberry MA, Vercoe PE, Martin GB: Level of nutrition affects leptin concentrations in plasma and cerebrospinal fluid in sheep. J Endocrinol 2000;165:625-637.

47 Szymanski LA, Schneider JE, Friedman MI, Ji H, Kurose Y, Blache D, Rao A, Dunshea FR, Clarke IJ: Changes in insulin, glucose and ketone bodies, but not leptin or body fat content precede restoration of luteinising hormone secretion in ewes. J Neuroendocrinol 2007;19:449-460.

48 McShane TM, Petersen SL, McCrone S, Keisler DH: Influence of food restriction on neuropeptide-Y, proopiomelanocortin, and luteinizing hormone-releasing hormone gene expression in sheep hypothalami. Biol Reprod 1993;49:831-839.

49 Clarke IJ, Cummins JT: The temporal relationship between gonadotropin releasing hormone $(\mathrm{GnRH})$ and luteinizing hormone (LH) secretion in ovariectomized ewes. Endocrinology 1982;111:1737-1739.

50 Watanobe H: Leptin directly acts within the hypothalamus to stimulate gonadotropinreleasing hormone secretion in vivo in rats. J Physiol 2002;545:255-268.

51 Finn PD, Cunningham MJ, Pau KY, Spies HG, Clifton DK, Steiner RA: The stimulatory effect of leptin on the neuroendocrine reproductive axis of the monkey. Endocrinology 1998;139:4652-4662.

52 Adam CL, Findlay PA, Miller DW: Bloodbrain leptin transport and appetite and reproductive neuroendocrine responses to intracerebroventricular leptin injection in sheep: influence of photoperiod. Endocrinology 2006;147:4589-4598.

53 Kurose Y, Iqbal J, Rao A, Murata Y, Hasegawa Y, Terashima Y, Kojima M, Kangawa K, Clarke IJ: Changes in expression of the genes for the leptin receptor and the growth hormone-releasing peptide/ghrelin receptor in the hypothalamic arcuate nucleus with long-term manipulation of adiposity by di- etary means. J Neuroendocrinol 2005; 17 : 331-340.

54 Korner J, Savontaus E, Chua SC Jr, Leibel RL, Wardlaw SL: Leptin regulation of Agrp and Npy mRNA in the rat hypothalamus. J Neuroendocrinol 2001;13:959-966.

55 Leadem CA, Kalra SP: Effects of endogenous opioid peptides and opiates on luteinizing hormone and prolactin secretion in ovariectomized rats. Neuroendocrinology 1985;41: 342-352.

56 Goodman RL, Coolen LM, Anderson GM, Hardy SL, Valent M, Connors JM, Fitzgerald ME, Lehman MN: Evidence that dynorphin plays a major role in mediating progesterone negative feedback on gonadotropin-releasing hormone neurons in sheep. Endocrinology 2004;145:2959-2967.

57 Walsh JP, Clarke IJ: Effects of central administration of highly selective opioid mu-, delta- and kappa-receptor agonists on plasma luteinizing hormone $(\mathrm{LH})$, prolactin, and the estrogen-induced LH surge in ovariectomized ewes. Endocrinology 1996;137:36403648.

58 Clarke IJ, Pompolo S: Synthesis and secretion of GnRH. Anim Reprod Sci 2005;88: 29-55.

59 Castellano JM, Navarro VM, FernándezFernández R, Nogueiras R, Tovar S, Roa J, Vazquez MJ, Vigo E, Casanueva FF, Aguilar E, Pinilla L, Dieguez C, Tena-Sempere M: Changes in hypothalamic KiSS-1 system and restoration of pubertal activation of the reproductive axis by kisspeptin in undernutrition. Endocrinology 2005;146:3917-3925.

60 Mizuno TM, Kleopoulos SP, Bergen HT, Roberts JL, Priest CA, Mobbs CV: Hypothalamic pro-opiomelanocortin mRNA is reduced by fasting and [corrected] in ob/ob and $\mathrm{db} / \mathrm{db}$ mice, but is stimulated by leptin. Diabetes 1998;47:294-297.

61 Jegou S, El Yacoubi M, Mounien L, Ledent C, Parmentier M, Costentin J, Vaugeois JM Vaudry H: Adenosine A2A receptor gene disruption provokes marked changes in melanocortin content and pro-opiomelanocortin gene expression. J Neuroendocrinol 2003; 15:1171-1177.

62 Mountjoy KG, Mortrud MT, Low MJ, Simerly RB, Cone RD: Localization of the melanocortin-4 receptor (MC4-R) in neuroendocrine and autonomic control circuits in the brain. Mol Endocrinol 1994;8:1298-1308.

63 Bunel DT, Delbende C, Blasquez C, Jegou S, Vaudry H: Characterization of alpha-melanocyte-stimulating hormone (alpha-MSH)like peptides in discrete regions of the rat brain. In vitro release of alpha-MSH from perifused hypothalamus and amygdala. Brain Res 1990;513:299-307.

64 Iqbal J, Pompolo S, Dumont LM, Wu CS, Mountjoy KG, Henry BA, Clarke IJ: Longterm alterations in body weight do not affect the expression of melanocortin receptor-3 and -4 mRNA in the ovine hypothalamus. Neuroscience 2001;105:931-940. 